\title{
Evaluation of Regional Development Policies in Turkey's Five Years Development Plans
}

\author{
Yasar Akca \\ ${ }^{1}$ Faculty of Economics and Administrative Sciences, Bartın University, Bartın, Turkey \\ Correspondence: Yasar Akca, Faculty of Economics and Administrative Sciences, Bartın University, Bartın, \\ Turkey. Tel: 90-378-223-5368.
}

Received: November 17, 2017

Accepted: January 24, 2018 Online Published: February 3, 2018

doi:10.5539/jms.v8n1p104

URL: https://doi.org/10.5539/jms.v8n1p104

\begin{abstract}
Five years development plans are prepared by State Planning Organization (former name), Ministry of Development. Development Plans are significant policy documents including information about resources of development goals in long term and related regulations to be made in Turkey. Ten different development plans including the years between 1963 and 2018 were prepared. The common basic goal of these plans is: Ensuring a fortunate and prosperous life for Turkish citizens, raising life standards to higher levels. Reaching more prosperous life standards is possible through a long term and systematic development effort. Regions including cities (except metropolis), districts and villages are called rural areas. Efforts for increasing the economic level of people living in rural areas by using and supporting natural resources in these areas are named regional development policies. Regional development policies are firstly determined and shaped in development plans. Economic activities in rural areas are mostly based on natural production resources. Regional development is only possible through efficient use of these local resources. The basic goal is to decrease the difference in the level of economic, social and cultural development between development priority regions and the others. The goal of this study is to present the preparations that should be made and focus on present and future problems. Qualitative design document analysis technique is used in this research; local development policies that are mentioned in ten development plans are analyzed. Findings, results and suggestions are presented at the end of the study.
\end{abstract}

Keywords: development plans, regional development policies, priority regions for development, rural are investments

\section{Introduction}

Goals of development are being able to meet the demands of public, increase the level of social prosperity and create fields of employment. Sharers of development are cooperation among managements, businessmen and public. Today, Turkish nation is quite willing to develop culturally, economically and socially. Ensuring this goal is possible only through increasing savings and investments. Development plans show resources that be utilized efficiently, organizations to be planned and precautions to be taken in order to reach the goals as a whole. The basic goals of development plans are to increase productivity and export, to increase the shares of agricultural development and industrial production, increase employment, decrease unemployment, change the share of income in favor of low income groups, support and accelerate development of underdeveloped regions with natural resources.

Three basic elements of rural development are industrialization, modernization in agriculture and urbanization (SPO, 1968, p. 263). These factors should be taken into consideration along with the policy decisions. Urbanization tendency should be supported with industrialization. Although Turkey has significant natural resources, there are inequalities among regions in terms of volume of activity and income level. Some places in the country are especially economically underdeveloped. It is not possible to determine these areas with absolute geographic borders. While there may be underdeveloped parts in a developed region, there may also be developed areas in an underdeveloped region.

One of the factors of development is to end and prevent inequalities among regions (SPO, 1963, p. 527). Not being able to establish sustainable and permanent basis for rural development increases differences in terms of the level of welfare between rural and urban areas and causes rural depopulation. Rural development policies are 
significantly emphasized in development plans. For this purpose, regional development goals for the priority regions for development are mentioned under seperate titles and related suggestions are made.

\section{Regional Development Policies}

The concept of regional development means the effort to transform low economic and social structures to industrialized social structures (SPO, 1972, p. 97). Rural areas with fertile soil and irrigation opportunities are more densely populated than the areas without these opportunities. Difficult topographic and climate conditions may decrease fertility in agricultural production, which decreases population. Goals of regional development are; increasing life standards of farmers, industrialization, efficient use of technology, solving the problem of unemployment, enhancing income distribution, increasing export, meeting the nutrition demands of population (SPO, 1972, pp. 208-209).

There are 49 priority regions for development in 2017. Cities in which per capita income is lower than $1500 \$$ are included in the priority regions for development (SPO, 2006, p. 46). These regions are $36 \%$ of total country population and $55 \%$ of total surface area. Problems and development priorities of regions are different from one another. Regional development policies are planned in order to decrease development differences.

A regional development policy is made of five factors:

1) Transportation and communication substructure should be supported and strengthened.

2) Water resources should be developed.

3) Land ownership and use should be improved.

4) Local administrations should be strengthened.

5) Human resources should be supported and developed.

While determining regional development plans, firstly the current situation is analyzed in terms of sectors and resources. Superior features of a region are evaluated by comparing it with other regions. Every region has special opportunities and problems. After this first step, regional development strategies are created. Middle and long term regional development plans are prepared in line with the regional development strategies. These plans should reflect local demands, ensure connection among sectors and develop a vision for the region. Region resources are attempted to be supported and utilized through development plans; thus, economic and social structure improves, new employment opportunities occur, income level increases and migration decreases.

\subsection{The First Five Years Development Plan (1963-1967)}

The main problems in this period were squatting and increasing unemployment levels, which were resourced from rapid urbanization (SPO, 1963, p. 28). In this plan period, these solutions were mentioned as regional development policy instruments:

- Investments should be supported and increased in order to solve the problem of unemployment. Import substitution investments should be increased. Significant steps should be taken in order to support the establishment of facilities by private sector in underdeveloped regions and in order to decrease production costs. Low establishment costs, affordable energy and credit, lower taxes and industrial estates should be ensured (SPO, 1963, p. 58).

- Fertilization and income in agriculture should be increased. Fertilizers and good seeds and proper pesticides should be used. Government should establish roads, increase opportunities for obtaining energy, communication and marketing; technical support should be given and land reforms should be made (SPO, 1963, p. 60).

- Cooperative organizations should be established (SPO, 1963, p. 101).

- Education on agriculture and related publishing processes are the basic significant of local development. Increasing the knowledge of peasants and correcting production techniques are significant points (SPO, 1963, p. 102).

- The order of land ownership should be reformed and lands should be used properly in order to obtain and maintain maximum yield. Precautions should be taken in order to protect lands from water and soil erosion (SPO, 1963, p. 174).

- Investments should be made in order to use water distribution canals and irrigation facilities properly (SPO, 1963, p. 176).

- Vegetative production and husbandry should be made together in agriculture facilities (SPO, 1963, p. 182), husbandry facilities should be supported, and livestock and meat exportation should be increased (SPO, 1963, p. 
182).

- Crafts such as weaving, stone dressing, the art of tile making should be supported and developed (SPO, 1963, p. 364). Turkish carpet business and handicrafts should be supported in order to be able to enter foreign markets (SPO, 1963, p. 361). Handicrafts will contribute to obtain significant additional income for agriculture population.

- Variety of agricultural materials should be increased and aquaculture exportation should be expanded.

- Income through tourism should be increased by supporting related organizations.

- Mercantile marine income should be increased.

- Production instruments should be produced in Turkish facilities.

\subsection{The Second Five Years Development Plan (1968-1972)}

In this period, it was especially mentioned that Turkey had to accelerate industrialization process and increase foreign trade volume. Young and dynamic population, fertile lands, variety of natural resources were the most significant factors affecting the development process (SPO, 1968, p. 42). In this plan period, these regional development policy instruments are mentioned as solutions:

- Fertilization, irritation and use of certified seed increases agricultural production export (SPO, 1968, p. 92).

- Roads, schools, electric, irrigation water opportunities should be given to villages (SPO, 1968, p. 235). More vets, agricultural engineers, teachers and doctors should serve in villages.

- Problems based on technology, production instruments, marketing should be solved through cooperatives in order to increase agricultural production (SPO, 1968, p. 235). Producers and markets should be more directly connected.

- Forestation processes should be supported (SPO, 1968, p. 248).

- Farmers should be supported in order to grow different kinds of products, especially forage crops (SPO, 1968, p. 248).

- Water resources, forage and forests in villages should be protected.

- Resources that can be developed and used in these regions should be determined and advertized, investors should be informed (SPO, 1968, p. 269).

- Developed Technologies should be used instead of traditional methods in agriculture. For this purpose, small scale industries producing agriculture instruments should be prioritized in the process of development (SPO, 1968, p. 544).

- Turkish handicrafts should be supported as a source of income (SPO, 1968, p. 545).

- Dependence of agriculture on weather conditions should be decreased, technical services in production should be developed.

- Farmers should have more affordable input.

\subsection{The Third Five Years Development Plan (1973-1977)}

Policies that were planned to be carried out in priority regions for development are;

- Developing breeding, dairies, poultry husbandry and stock projects are significant (SPO, 1972, p. 251).

- Farmer families who haven't got any lands or the ones who have got small lands should be supported in order to make more production or obtain efficiency (SPO, 1972, p. 913).

- Water resources and groundwater facilities should be developed (SPO, 1972, p. 861).

- Health care facilities, basic education and regional primary boarding schools, vaccination and artificial insemination stations, PTT branches should be established in villages (SPO, 1972, p. 865).

- Agriculture, forestry, breeding, aquaculture and handicrafts should be supported (SPO, 1972, p. 865).

- Storage, transportation and marketing processes should be supported by cooperatives (SPO, 1972, p. 865).

- Inputs that increase yield such as fertilizers, seeds, pesticides should be used and irrigation should be developed, higher technology should be efficiently used, forage and grain agriculture should be developed (SPO, 1972, p. 210).

- Connection between agricultural production and food industry should be established and used (SPO, 1972, p. 
211).

- Increasing production in agriculture is possible by using soil according to its features. Increasing the number of analytical laboratories which will ensure fertilizer-plant-soil unity should be increased, they should be developed in order to ease the work of farmers (SPO, 1972, p. 253).

- Government should support fighting with animal diseases, give priorities to priority regions for development in terms of stockfarming and establishing meat industries (SPO, 1972, p. 253).

- Agricultural products should be a part of insurance coverage.

2.4 The Fourth Five Years Development Plan (1979-1983)

Main regional development policies included in this development plan are presented below;

- Public enterprises such as apiculture, silkworm-breeding, poultry husbandry should be supported and extended; new projects should be designed and applied in order to decrease unemployment (SPO, 1979, p. 4).

- Cultivable soil should be used efficiently in order to grow proper vegetables (SPO, 1979, p. 228).

- Irrigation, soil protection and reformation processes should be practiced properly in order to increase yield (SPO, 1979, p. 228).

- Turkey is very suitable for animal husbandry as it has significant natural resources and forages. Demand of increasing population and exportation potential of animal products are significant factors which necessitate increasing animal husbandry (SPO, 1979, p. 357).

- Irrigation techniques that ensure water saving should be prioritized.

- Slaughtering animals before proper periods should be prevented.

- Production of fish according to the features of inland water should be encouraged.

- Agriculture based industry should be developed, road connections should be enhanced.

- Private entrepreneurs focusing on using regional resources efficiently should be encouraged.

- Use of fertilizers based on soil analysis should be extended.

- Tourism and foreign mercantile marine should be developed.

\subsection{The Fifth Five Years Development Plan (1985-1989)}

Main regional development policies included in this development plan are presented below;

- Agriculture and animal husbandry investments focusing on meeting the demands of neighboring countries should be increased (SPO, 1984, p. 32).

- Public investments on agriculture should focus on irrigation, drainage and soil improvement.

- Producing and using quality seed should be prioritized.

- Integrated facilities for meat and egg poultry should be established and supported (SPO, 1984, p. 40).

- Private sector investments should be directed towards animal breeding, fruit nursery, seed growing, greenhouse cultivation and floriculture for exporting (SPO, 1984, p. 53).

2.6 The Sixth Five Years Development Plan (1990-1994)

Main regional development policies included in this development plan period are presented below;

- Land consolidation of agricultural lands should be prioritized (SPO, 1989, p. 51).

- Oily seeds and industrial crops development programs should be encouraged, forage legumes plantation areas should be extended (SPO, 1989, p. 52).

- Planting a second kind of seed should be encouraged; quality, fertile raw vegetable and fruits cultivation, greenhouse cultivation and floriculture should be encouraged and supported (SPO, 1989, p. 52).

- Dairy farming, stockfarming, poultry, apiculture and silkworm-breeding should be developed (SPO, 1989, p. 56).

-Use of tractor and agricultural machines should be increased and production of them should be encouraged (SPO, 1989, p. 226).

- Establishing organized industrial estates should be continued (SPO, 1989, p. 318).

- Government should continue pioneering in the process of establishing production, mining and related industries 
in development priority regions (SPO, 1989, p. 319).

- Border trades in border gates should be developed (SPO, 1989, p. 319).

- Working in new production lines in rural areas should be encouraged and nonagricultural economic activity branches should be supported (SPO, 1989, p. 321).

- Informal education programs should be diversified in order to increase educational and cultural level of families living in agricultural regions (SPO, 1989, p. 321).

- Agricultural product support prices should be determined in a way that they provide stability in farmer income.

\subsection{The Seventh Five Years Development Plan (1996-2000)}

In this plan period, it was mentioned that agricultural lands had been reduced because of the use of agricultural lands for non-agricultural purposes and erosion (SPO, 1995, p. 57). It was determined and mentioned that income of employees working in agricultural fields was below the income of employees in other sectors (SPO, 1995, p. 57). Regional development policy instruments in this plan period are mentioned below;

- Increasing irrigated lands, using quality stock and seed, making soil analysis, using fertilizers and technical equipments properly, carrying out agricultural pest control and common education activities are the main goals (SPO, 1995, p. 60).

- In order to solve the problem of unemployment in development priority regions, growing fruits and vegetables, industrial plants, husbandry, and similar processes should be supported. Industries that will support processing of these products should be established (SPO, 1995, p. 175).

- Labor-intensive projects, primarily housing industry, should be supported (SPO, 1995, p. 175).

-Activities such as husbandry, agriculture, handicrafts based on the features of the region should be supported (SPO, 1995, p. 175).

- Entrepreneurship development projects will be practiced (SPO, 1995, p. 177).

- Contractual cultivation will be extended.

- Counseling and guiding services for entrepreneurship will be given.

-Establishing of industries which support production of industrial crops which have high additional value should be supported; industries which process these products should be established.

\subsection{The Eighth Five Years Development Plan (2001-2005)}

The main problems of previous periods such as lack of quality workforce, entrepreneurship and incompetency in marketing were still significant in this period (SPO, 2000, p. 62). Regional development policies of this plan period are stated below;

- Skill courses and vocational courses should be extended (SPO, 2000, p. 70).

- Developing family-owned businesses will be supported and accelerated (SPO, 2000, p. 70).

- Pasture improvement and management processes should be prioritized (SPO, 2000, p. 70).

- Lack of agricultural studies, publishing and education, non-professional fertilization and use of pesticides, stubble burning and fallowing have negative effect on agriculture (SPO, 2000, p. 71).

- Agriculture based industry, packaging, storage and marketing methods should be technically supported (SPO, 2000, p. 71), transportation infrastructure should be improved.

- Enterprises such as tourism, handicrafts and breeding should be supported (SPO, 2000, p. 71).

- Local radio and television channels should be supported in order to contribute to the education of people in the region.

- Female population's knowledge and abilities should be increased through courses.

\subsection{The Ninth Five Years Development Plan (2007-2013)}

In this period, firstly current situation was determined and analyzed. Low yield per animal and insufficient forage crop production were significant problems (SPO, 2006, p. 31). Energy and zero rate land supports were given (SPO, 2006, p. 46). Development Agencies for local and regional development were established in order to develop cooperation between private, public and civil society organizations (SPO, 2006, p. 47). European Union supported regional development programs were held (SPO, 2006, p. 48). Regional development policy instruments mentioned in this plan period are presented below; 
- Application of modern irrigation techniques, focusing on competitive product types, developing marketing processes are significant (SPO, 2006, p. 47).

- In order to decrease the ineffectiveness in agriculture, on which significant amount of people depend, land consolidation, enforcing producer organizations, education and publishing activities should be supported and extended (SPO, 2006, p. 49).

- E-commerce should be used in rural areas, agriculture, forest, food, tourism, handicrafts should be developed (SPO, 2006, p. 93).

- EU supported regional development programs should be carried out and agricultural supports should be enriched through different and efficient practices.

\subsection{The Tenth Five Years Development Plan (2014-2018)}

Before the start of this plan period, a detailed situational analysis had been carried out. It was determined that, if agricultural production costs decrease and yield increase, then food prices would decrease (Ministry of Development, 2013, p. 14). It was mentioned that based on their increasing population and income, Middle East, North Africa and Near East countries would probably become bigger foreign markets for Turkey in terms of food products (Ministry of Development, 2013, p. 14). In regional level, 26 development agencies and investment support offices in 81 cities entered into service (Ministry of Development, 2013, p. 25). In this plan period, regional development plans that were suggested to be applied are presented below:

- Production and employment structure of rural economy should be diversified with non-agricultural activities such as tourism, trade, food industry, small-scaled production (Ministry of Development, 2013, pp. 135-136).

- Capacities of small industrial sites should be increased and micro-enterprises should be developed.

- In low income and geographically disadvantaged regions, human capital should be developed through distance education programs and e-learning.

- Regional necessities should be the basis of using European Union supported funds.

\section{Result}

Increasing the life quality of individuals in where they live is the basic point of sustainability. The basic goals of rural development policies are improving work and life conditions, empowering employment, developing human resources, decreasing poverty, enhancing social and physical substructure and protecting environmental and natural resources. For ensuring development, education, health, social security and other government services should be corrected and developed while industry is empowered. Education should be extended, health conditions should be improved, affordable residence programs and new employment opportunities are significant factors which will accelerate development. In recent years, economy in Turkey has been developing. There is a significant increase in income per capita and level of welfare. But these progresses haven't been equal in terms of regions. Regional development policies aim at decreasing these development differences. There is a significant difference between east-west, coastal/interior regions in terms of socioeconomic development. Reaching high standards in life in Turkey is possible only when long term and systematic development efforts are given. Finally it should be mentioned that, high virtues, ambition to work, belief in equity, power of entrepreneurship and moral courage are unique features of Turkish people and they will continue to form the basis of most valuable resources that will lead to development.

\section{References}

T.C. Başbakanlık Devlet Planlama Teşkilatı Müsteşarlığı. (1963). Birinci bes yıllık kalkınma planı (1963-1967). Ankara: Başbakanlık Devlet Matbaası. Retrieved from http://ekutup.dpt.gov.tr/plan1.pdf

T.C. Başbakanlık Devlet Planlama Teşkilatı Müsteşarlığı. (1968). İkinci Beş Yıllık Kalkınma Planı (1968-1972). Ankara: Başbakanlık Devlet Matbaası. Retrieved from http://ekutup.dpt.gov.tr/plan2.pdf

T.C. Başbakanlık Devlet Planlama Teşkilatı Müsteşarlığı. (1972). Üçüncü Beş Yıllık Kalkınma Planı (1973-1977). Ankara: DPT Yayın No: 1272. Retrieved from http://ekutup.dpt.gov.tr/plan3.pdf

T.C. Başbakanlık Devlet Planlama Teşkilatı. (1978). Dördüncü Beş Yıllık Kalkınma Planı (1979-1983). Ankara: DPT Yayın No: 1664, Retrieved from http://ekutup.dpt.gov.tr/plan4.pdf

T.C. Başbakanlık Devlet Planlama Teşkilatı. (1984). Beşinci Beş Yıllık Kalkınma Planı (1985-1989). Ankara: DPT Yayın No: 1974. Retrieved from http://ekutup.dpt.gov.tr/plan/plan5.pdf

T.C. Başbakanlık Devlet Planlama Teşkilatı. (1989). Altıncı Beş Yıllık Kalkınma Planı (1990-1994). Ankara: 
DPT Yayın No: 2174, Retrieved from http://ekutup.dpt.gov.tr/plan/plan6.pdf

T.C. Başbakanlık Devlet Planlama Teşkilatı. (1995). Yedinci Beş Yıllık Kalkınma Planı (1996-2000), Ankara: 25 Temmuz 1995 Sayılı Resmi Gazete No: 22554. Retrieved from http://ekutup.dpt.gov.tr/plan/vii/plan7.pdf

T.C. Başbakanlık Devlet Planlama Teşkilatı. (2000). Sekizinci Beş Yıllık Kalkınma Planı (2001-2005), Ankara. Retrieved from http://ekutup.dpt.gov.tr/plan/viii/plan8str.pdf

T.C. Başbakanlık Devlet Planlama Teşkilatı. (2006). Dokuzuncu Kalkınma Planı (2007-2013), Ankara. Retrieved from http://ekutup.dpt.gov.tr/plan9.pdf

T.C. Kalkınma Bakanlığı. (2013). Onuncu Kalkınma Planı (2014-2018). Ankara. Retrieved from http://ekutup.dpt.gov.tr/plan10.pdf

\section{Copyrights}

Copyright for this article is retained by the author(s), with first publication rights granted to the journal.

This is an open-access article distributed under the terms and conditions of the Creative Commons Attribution license (http://creativecommons.org/licenses/by/4.0/). 